\title{
Testing the applicability of BIOME-BGC to simulate beech gross primary production in Europe using a new continental weather dataset
}

\author{
Marta Chiesi $^{1}$ - Gherardo Chirici ${ }^{2}$ - Marco Marchetti ${ }^{3}$ - Hubert Hasenauer ${ }^{4}$. \\ Adam Moreno $^{4} \cdot$ Alexander Knohl $^{5} \cdot$ Giorgio Matteucci $^{6} \cdot$ Kim Pilegaard $^{7}$. \\ André Granier ${ }^{8} \cdot$ Bernard Longdoz $^{8} \cdot$ Fabio Maselli $^{1}$
}

Received: 16 February 2016 / Accepted: 12 May 2016/Published online: 7 June 2016

(C) INRA and Springer-Verlag France 2016

\begin{abstract}
- Key message A daily 1-km Pan-European weather dataset can drive the BIOME-BGC model for the estimation of current and future beech gross primary production (GPP). Annual beech GPP is affected primarily by spring temperature and more irregularly by summer water stress.
\end{abstract}

Handling Editor: Thomas Wohlgemuth

Contribution of the co-authors Chiesi: running the data analysis and writing the paper; Chirici: supervising the work; Marchetti: coordinating the research project; Hasenauer and Moreno: producing the 1-km meteorological dataset; Knohl, Matteucci, Pilegaard, Granier, Longdoz: collecting and analysing the flux tower data; Maselli: supervising the work and running the data analysis.

Marta Chiesi

m.chiesi@ibimet.cnr.it

1 IBIMET-CNR, via Madonna del Piano 10, 50019 Sesto

Fiorentino, FI, Italy

2 Università degli Studi di Firenze, Via San Bonaventura, 13, 50145 Firenze, Italy

3 Università degli Studi del Molise, Contrada Fonte Lappone snc, 86090 Pesche, IS, Italy

4 University of Natural Resources and Life Sciences, Peter-Jordan Straße, 82, Vienna, Austria

5 Bioclimatology, University of Göttingen, Büsgenweg 2 , 37077 Göttingen, Germany

6 ISAFOM-CNR, Via Patacca 85, 80056 Ercolano, NA, Italy

7 Technical University of Denmark, 2800 Kgs, Lyngby, Denmark

8 UMR Ecologie et Ecophysiologie Forestières, UMR1137, Inra-Université de Lorraine, F-54280 Champenoux, France
- Context The spread of beech forests in Europe enhances the importance of modelling and monitoring their growth in view of ongoing climate changes.

- Aims The current paper assesses the capability of a biogeochemical model to simulate beech gross primary production (GPP) using a Pan-European 1-km weather dataset.

- Methods The model BIOME-BGC is applied in four European forest ecosystems having different climatic conditions where the eddy covariance technique is used to measure water and carbon fluxes. The experiment is in three main steps. First, the accuracy of BIOME-BGC GPP simulations is assessed through comparison with flux observations. Second, the influence of two major meteorological drivers (spring minimum temperature and growing season dryness) on observed and simulated inter-annual GPP variations is analysed. Lastly, the impacts of two climate change scenarios on beech GPP are evaluated through statistical analyses of the ground data and model simulations.

- Results The weather dataset can drive BIOME-BGC to simulate most of the beech GPP evolution in all four test areas. Both observed and simulated inter-annual GPP variations are mainly dependent on minimum temperature around the beginning of the growing season, while spring/summer dryness exerts a secondary role. BIOMEBGC can also reasonably predict the impacts of the examined climate change scenarios.

- Conclusion The proposed modelling approach is capable of approximately reproducing spatial and temporal beech GPP variations and impacts of expected climate changes in the examined European sites.

Keywords Weather dataset · Beech forest - GPP . BIOME-BGC $\cdot$ Eddy covariance 


\section{Introduction}

Beech forests (Fagus sylvatica L.) characterize the landscape of many parts of Europe, from the northern regions where these forests grow at low elevations to the Mediterranean countries where they are spread on mountain areas (Bolte et al. 2007). European beech is, in fact, the most widely distributed deciduous forest tree species over all of Central Europe, where it also represents the potential natural vegetation (Fig. 1). It is a successful competitor against other species mainly due to its extreme shade tolerance, which makes it virtually the only species able to regenerate under very limited light conditions (Ellenberg 1988). Beech grows well on a wide range of soils, both acidic and basic, but dry soils and flooding areas do not favour its growth. From a climatic point of view, beech prefers a maritime, temperate climate with mild winters and moist summers; therefore, it is absent from areas with long and severe winters and/or intense summer dryness (Aranda et al. 2000; Bréda et al. 2006; Vitale et al. 2012). This species has historically been and is still a fundamental economic resource, being utilized to produce timber and furniture, firewood and charcoal.

Estimating beech ecosystem processes and their variation in space and time is therefore essential for numerous purposes, including advancing towards sustainable management of forest resources and studying the effects of global changes (IPPC 2014). It has been clearly demonstrated that large-scale perturbations, such as global climate change or air pollution, affect the equilibrium of forests and their interaction with the hydrosphere and atmosphere (Waring and Running 2010). Different tools are available to monitor the main processes of terrestrial ecosystems, such as local observations and experiments, inventories, dendro-ecological studies, simulation models and remote sensing techniques (e.g. Chiesi et al. 2005; Powell et al. 2010). While each of these tools provides information on a specific aspect, only simulation models can be applied in a prognostic way to hypothesize the effects of global environmental changes at various spatial and temporal scales (Turner et al. 2006; Chiesi et al. 2011; Huber et al. 2013). One of these models is the biogeochemical BIOMEBGC which has been successfully applied in a large number of investigations all over the world (e.g. Law et al. 2004; Ichii et al. 2005; Chiesi et al. 2007; Tatarinov and Cienciala 2009; Ueyama et al. 2009; Pötzelsberger et al. 2015).

The use of this model for regional-scale studies requires the availability of spatially extended daily weather datasets with a suitable resolution, typically around $1 \mathrm{~km}$ (Hofstra et al. 2009). While these datasets have been produced for the conterminous USA (Thornton et al. 1997), up to now this has not been the case for the continent of Europe, where the existing long-term daily weather datasets have lower spatial resolution. For example, the dataset of minimum and maximum temperature and rainfall released by Haylock et al. (2008) (E-OBS) has a grid size of $0.25^{\circ}$ (about $30 \mathrm{~km}$ ). Concerning only the Italian national territory, a first attempt was made by Maselli et al. (2012) to downscale the E-OBS dataset to 1-km resolution. More recently, this work has been extended by Moreno and Hasenauer (2015) to perform a similar downscaling for the whole of Europe.

The objective of the current paper is to assess the capability of BIOME-BGC to simulate beech gross primary production (GPP) using this spatially extended 1-km E-OBS dataset under present and expected climatic conditions. With this aim, four sites were selected on a European north-south environmental gradient where reference GPP data have been collected through the eddy covariance technique (Aubinet et al. 2000). These reference data were first used to assess the accuracy of BIOME-BGC simulations of beech GPP. Minimum temperature at the beginning of the growing season and spring-summer dryness were then tested as the meteorological factors most influential on inter-annual variations of both observed and simulated GPP. The effects of two different climate change scenarios were lastly investigated by comparing the results of statistical analyses of GPP measurements and model simulations.

\section{Materials and methods}

\subsection{Study sites}

The four beech forest sites selected for the investigation are listed in Table 1 together with their main characteristics. These sites, in which beech accounts for more than $70 \%$ of the total basal area, are situated in four countries and represent wide latitudinal (from $55^{\circ}$ to $42^{\circ} \mathrm{N}$ ) and altitudinal (from $40 \mathrm{~m}$ to $1550 \mathrm{~m}$ a.s.l.) gradients (Fig. 1). In all sites, which belong to the FLUXNET network (see http://www.europe-fluxdata.eu/home/sites-list), the eddy covariance technique has been applied during the decade 2000-2009 to continuously measure the ecosystem net carbon exchange (NEE) and then retrieve the GPP after estimating nighttime respiration (Reichstein et al. 2005).

The Soroe site is situated in Denmark; its climate is temperate maritime and is characterized by cool summers and mild windy winters. Its brown soils are classified as either Alfisols or Mollisols with a 10-40 cm deep organic layer. The average tree height of the beech forest is $26 \mathrm{~m}$, the average tree diameter is $38 \mathrm{~cm}$ and stand density is $283 \mathrm{stems} \mathrm{ha}^{-1}$ (Pilegaard et al. 2011).

The Hainich site is in Thuringia (Central Germany); its climate is suboceanic-submontane. Soils are formed on Triassic limestone covered with variable Pleistocene loess deposits. The ecosystem can be classified as an old-growth forest with tree ages ranging from 0 to 250 years with a highly diverse horizontal and vertical structure (Knohl et al. 2003; Mund 2004). The area was never clear-cut, and there was only limited felling until 1997, with no management activity at all after 1997. Beech is the dominant tree species (about $64 \%$ of 


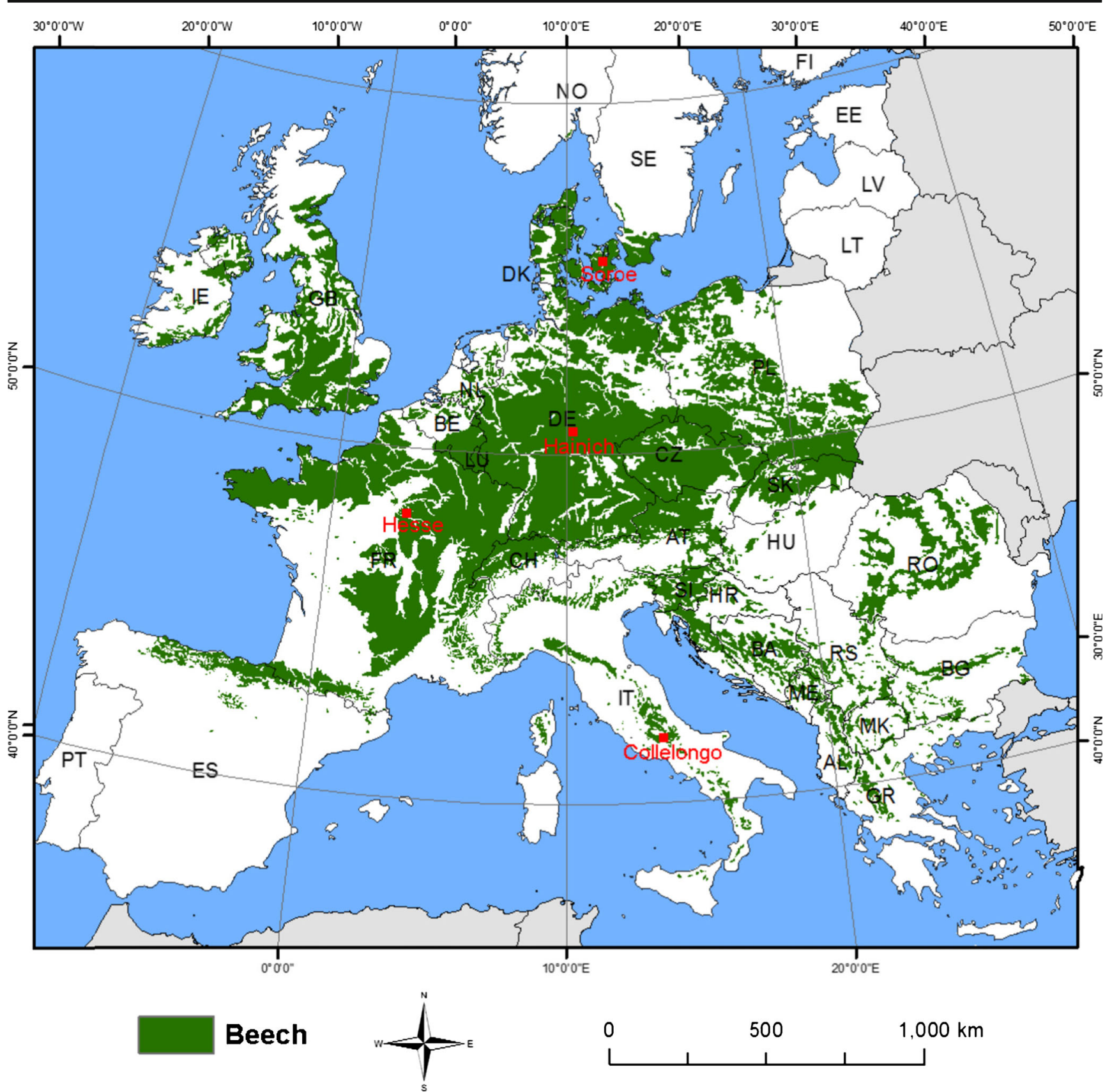

Fig. 1 Map of potential beech distribution in Europe (Bohn et al. 2004) with geographical position of the four study sites

tree biomass), followed by ash (Fraxinus excelsior L., $28 \%$ ), sycamore (Acer pseudoplatanus L., 7 \%) and other single deciduous trees (Mund et al. 2010).

The Hesse site is in Eastern France. The soil type is Luvisol/Stagnic Luvisol, and clay content is around $35 \%$. The forest is dominated beech (about $95 \%$ in terms of composition) plus other deciduous tree species. Mean tree height was around $17 \mathrm{~m}$ in 2005, and basal area was $20.7 \mathrm{~m}^{2} \mathrm{ha}^{-1}$. Due to canopy closure, understory vegetation is very sparse (Granier et al. 2008).

Collelongo is in Central Italy. It has a Mediterranean mountain climate, with cool summers and cold winters (Scartazza et al. 2013). Soil is classified as a humic alisol. The flux tower site is surrounded by a beech forest with a stand density of 825 trees $\mathrm{ha}^{-1}$, the mean age in 2008 was 115 years, basal area was $40.6 \mathrm{~m}^{2} \mathrm{ha}^{-1}$ with a mean diameter of $25 \mathrm{~cm}$ and mean height of $21.2 \mathrm{~m}$ (Guidolotti et al. 2013).

\subsection{Study data}

Daily weather data needed to initialize BIOME-BGC were obtained from a Pan-European level 1-km daily dataset produced recently by Moreno and Hasenauer (2015) downscaling the original E-OBS dataset (Haylock et al. 2008). 
Table 1 Main geographical and climatic characteristics of the four beech study sites (see also Pilegaard et al. 2011; Granier et al. 2008 ; Knohl et al. 2003; Scartazza et al. 2013)

\begin{tabular}{|c|c|c|c|c|c|c|c|}
\hline Site & Country & Position $\left(^{\circ}\right)$ & $\begin{array}{l}\text { Altitude } \\
\text { (m a.s.1.) }\end{array}$ & $\begin{array}{l}\text { Soil depth } \\
\text { (m) }\end{array}$ & $\begin{array}{l}\text { Soil texture } \\
\text { (\% sand, silt, clay) }\end{array}$ & $\begin{array}{l}\text { Mean annual } \\
\text { temperature }\left({ }^{\circ} \mathrm{C}\right)\end{array}$ & $\begin{array}{l}\text { Mean annual } \\
\text { rainfall }(\mathrm{mm})\end{array}$ \\
\hline Soroe & Denmark & $55.49 \mathrm{~N}, 11.65 \mathrm{E}$ & 40 & 1.5 & $54,32,14$ & 8.5 & 564 \\
\hline Hainich & Germany & $51.07 \mathrm{~N}, 10.45 \mathrm{E}$ & 445 & 0.6 & $4,56,40$ & $7.5-8$ & $750-800$ \\
\hline Hesse & France & $48.67 \mathrm{~N}, 7.07 \mathrm{E}$ & 300 & 1.5 & $6,67,27$ & 9.2 & 820 \\
\hline Collelongo & Italy & $41.55 \mathrm{~N}, 13.59 \mathrm{E}$ & 1570 & 0.8 & $30,40,30$ & 7.1 & 1088 \\
\hline
\end{tabular}

The major benefit of these downscaled data is the inclusion of the orographic effects on a local scale in the original E-OBS dataset (Moreno and Hasenauer 2015). A daily dataset of minimum and maximum temperature and precipitation from 1950 to 2013 is now freely and publically available at ftp:// palantir.boku.ac.at/Public/ClimateData/.

The reference daily weather and GPP data of the four study sites were obtained from the European Fluxes Database Cluster (http://www.europe-fluxdata.eu/home/sites-list) (see Table 1). The $\mathrm{CO}_{2}$ fluxes of these sites were measured by applying the eddy covariance technique following the standard EUROFLUX methodology (Aubinet et al. 2000; Baldocchi 2003). The flux data utilized in this study belong to level 4, meaning that the daily data have been gap-filled, filtered and quality checked following the database's methodology; partitioning the net $\mathrm{CO}_{2}$ fluxes in GPP and ecosystem respiration is then done using the approach by Reichstein et al. (2005).

The analysis uses data collected during the decade 2000 2009 for all sites with the exception of Hainich, for which the reference period is 2000-2007.

\subsection{Data analysis}

\subsubsection{Assessment of BIOME-BGC GPP estimates}

BIOME-BGC is a biogeochemical model that can estimate the storage and fluxes of water, carbon and nitrogen within terrestrial ecosystems (Running and Hunt 1993). As input, it requires daily weather data (i.e. minimum and maximum temperature, precipitation, solar radiation, vapour pressure deficit and day length) and information on the environment (i.e. altitude, latitude, soil texture and depth, etc.); it also requires parameters describing the eco-physiological characteristics of vegetation. BIOME-BGC is capable of finding a quasiequilibrium with local eco-climatic conditions through the spin-up phase, which quantifies the initial amount of all carbon and nitrogen pools. This enables proceeding towards the estimation of all fluxes and allocation processes for the study years (Churkina et al. 2003).

The version of the model used (BIOME-BGC version 4.2) was calibrated for European beech in Italy following the methodology described in Chiesi et al. (2007), introducing two modifications. The first concerned the activation of the model phenology option, aimed at allowing weather-driven inter-annual variations in the start and end of the growing seasons. As fully explained by White et al. (1997), these phenological phases are determined based on site temperature, radiation and day length; more particularly, the start of the season is predicted on the basis of temperature and radiation summations, while the end is simulated including the effect of day length. Second, the parameters related to the maximum photosynthetic efficiency (i.e. the content of leaf nitrogen in Rubisco) and maximum stomata conductance were modified to account for a model tendency to underestimate beech GPP that was highlighted by Chirici et al. (2016). Both modifications were made following the calibration exercise conducted by Pietsch et al. (2005) at Pan-European level. A summary of the ecophysiological parameters finally adopted is reported in Table 6 .

None of the selected study sites has the complete daily weather data of the 10-year study period which were required for running BIOME-BGC in a spin-up-and-go mode. Daily minimum and maximum air temperature and precipitation were therefore derived from the downscaled E-OBS dataset of Moreno and Hasenauer (2015). Daily global solar radiation was then estimated by the mountain microclimate simulator (MT-CLIM) algorithm (Thornton et al. 2000) and converted into PAR through a coefficient equal to 0.464 (Iqbal 1983).

Precise information on soil depth and texture was not available for all sites. In particular, soil depth was uncertain, which directly controls BIOME-BGC simulation of water retention capacity and, consequently, evapotranspiration and photosynthesis processes (Chiesi et al. 2011). For example, the soil depth reported for Soroe ranges from 0.5 to $2.5 \mathrm{~m}$ (Trusilova et al. 2009); at Hainich and Collelongo, the soil depth is around $0.5-0.6$ and $0.8 \mathrm{~m}$, respectively, but with wide spatial variations due to the presence of a rocky substrate (Knohl et al. 2003; Chiti et al. 2010). The low spatial resolution soil maps that could be used to drive the model application on a regional scale are affected by similar or even higher uncertainty (Zhu 1997). For this reason, the mean values of the soil information reported in the cited literature were utilized (see Table 1). Next, BIOME-BGC was applied to estimate the daily GPP of the decade 2000-2009 for all sites. 
The accuracy assessment was made using all available daily eddy covariance measurements from each study site. The GPP estimated from the model for each site was compared to the respective eddy covariance observations both averaged for a complete annual profile and on a daily basis. The results of the comparisons were summarized by means of common accuracy statistics: coefficient of determination $\left(r^{2}\right)$, root mean square error (RMSE) and mean bias error (MBE), computed as the difference between estimated and measured averages.

The meteorological statistics reported in Table 2 confirm the findings of Maselli et al. (2012), i.e. that while the E-OBS dataset correctly reproduces mean temperature (maximum errors around $1{ }^{\circ} \mathrm{C}$ ), it variably underestimates annual rainfall (up to $30 \%$ ). The effects of these errors were assessed by linearly adjusting the E-OBS data to the common tower measurements of each study site. In the case of temperature, this was done by developing and applying site-specific linear regression equations between observed (tower) and E-OBS daily data, while the E-OBS daily rainfall data of each site were multiplied by a ratio between observed and E-OBS mean annual totals. No correction was applied to the precipitation patterns. The whole simulation experiment was then repeated using the corrected data, obtaining new GPP estimates that were re-evaluated as above against the available eddy covariance GPP data.

\subsubsection{Evaluation of the effect of temperature and water stress}

The second part of the analysis consisted of evaluating the influence of major environmental factors on the inter-annual variability of beech GPP for each site. European beech grows in temperate-humid zones, where both thermal and water limitations act with different intensities and in different periods of the year (Bréda et al. 2006). The thermal effect is dominant at the beginning of the growing season, when beech starts its "bud break" phase depending on photoperiod and air temperature (Falusi and Calamassi 1997). The water factor acts mainly in dry summer periods, when rainfall is low and the evaporative demand is maximum (Piovesan et al. 2008; Maselli et al. 2014).

Table 2 Mean temperatures and precipitations observed at each tower site and derived from the 1-km E-OBS dataset

\begin{tabular}{lllll}
\hline Site & $\begin{array}{l}\text { Mean } \\
\text { observed } \\
\text { annual } \\
\text { temperature } \\
\left({ }^{\circ} \mathrm{C}\right)\end{array}$ & $\begin{array}{l}\text { Mean 1-km E- } \\
\text { OBS annual } \\
\text { temperature } \\
\left({ }^{\circ} \mathrm{C}\right)\end{array}$ & $\begin{array}{l}\text { Mean } \\
\text { observed } \\
\text { annual } \\
\text { rainfall } \\
(\mathrm{mm})\end{array}$ & $\begin{array}{l}\text { Mean 1-km } \\
\text { E-OBS } \\
\text { annual } \\
\text { rainfall }(\mathrm{mm})\end{array}$ \\
\hline Soroe & 8.6 & 9.6 & 749 & 532 \\
Hainich & 8.3 & 8.4 & 806 & 757 \\
Hesse & 10.3 & 10.6 & 990 & 844 \\
Collelongo & 9.2 & 8.0 & 928 & 715 \\
\hline
\end{tabular}

The analysis was therefore focused on assessing the impact of spring temperature (from February to May) and springsummer dryness (from April to September) on both observed and simulated beech GPP. Concerning the GPP observations, the analysis was restricted to the years with complete daily flux measurements during the growing season. First, the growing season was divided into two parts around the mean start of the dry season (SDS), which indicates the period before and after which the effects of thermal and water limitations are expected to be most relevant, respectively (Maselli et al. 2014). The date corresponding to mean SDS was found for each site by using the water stress factor (Cws) proposed by Maselli et al. (2009); it was obtained from a normalized ratio between precipitation and potential evapotranspiration (PET), both cumulated over a 2-month period. Daily Cws values were computed for the four sites using the corrected daily rainfall and PET predicted by the method proposed by Jensen and Heise (1963). These values were then converted into SDS using the linear equation proposed by Maselli et al. (2014). Total GPPs before and after this date were then computed from both tower GPP observations and BIOME-BGC simulations.

The impact of spring temperature in the GPP of the first part of the growing season $\left(\mathrm{GPP}_{1}\right)$ was assessed using the MODIS temperature correction factor for deciduous broadleaved forests (Tcor). It is computed as a linear ramp function of daily minimum temperature and acts reducing photosynthesis when the ambient temperature is far from the optimum (Heinsch et al. 2003). A linear regression analysis was therefore performed for each test site between mean Tcor computed around the start of the growing season (independent variable) and the GPP of the first part of the season (dependent variable). After some trials, a 100-day period was identified for computing mean Tcor ranging from the end of February to the end of May. The effect of growing season dryness on the GPP of the second part of the growing season $\left(\mathrm{GPP}_{2}\right)$ was evaluated using Cws. In particular, new linear regression analyses were performed for each test site between the mean Cws of spring-summer (independent variable) and the observed and simulated GPP in the second part of the season (dependent variable).

\subsubsection{Analysis of the impact of expected climate changes}

The study concluded with an evaluation of the impact of two different emission scenarios: a medium-high non-mitigation baseline scenario (A1B) and a mitigation scenario (E1). The considered expected changes in temperature and precipitation for the whole Europe are given in Table 3; more details can be found in Christensen et al. (2011). These temperature and rainfall deltas were applied to modify the daily values of the meteorological data previously used, obtaining two new datasets. Their impact on beech GPP was evaluated by two methods: 
Table 3 Projected changes for global Europe in mean temperature $\left({ }^{\circ} \mathrm{C}\right)$ and precipitation (mm per season) for 2071-2100 minus the 1961-1990 baseline for the A1B and E1 emission scenarios for winter and summer (see Christensen et al. 2011, for details)

\begin{tabular}{llllll}
\hline & \multicolumn{2}{l}{ Temperature $\left({ }^{\circ} \mathrm{C}\right)$} & & \multicolumn{2}{l}{ Rainfall (mm/season) } \\
\cline { 2 - 3 } \cline { 5 - 6 } Scenario & Winter & Summer & & Winter & Summer \\
\hline A1B & 3.01 & 2.73 & & 9.53 & 8.57 \\
E1 & 1.53 & 1.40 & & 4.0 & 4.34 \\
\hline
\end{tabular}

- First, the temperature, precipitation and PET changes from the two scenarios were transformed into Tcor and Cws changes during the previously defined periods. The Tcor changes were, in turn, converted into GPP changes for the first part of the season using the slopes defined in the previous regression analyses. The same was done using the Cws changes for the second part of the season. Total annual GPP changes were finally reconstructed by summing the two GPP partials.

- Second, the same GPP changes were predicted by driving BIOME-BGC with the weather datasets of the A1B and E1 scenarios.

The GPP changes obtained by the statistical and simulation methods were finally inter-compared by the same statistics as above.

\section{Results}

\subsection{BIOME-BGC GPP estimates}

When examining the results of the simulations performed, two considerations should be kept in mind. First, all modelling exercises were driven exclusively by weather and soil data, both concerning the length of the growing season and the daily GPP magnitude. Second, the four sites examined cover different eco-climatic situations, where beech growth is variably controlled by thermal, water and edaphic constraints. As previously noted, these two facts assure the wide applicability of the method and representativeness of the results but also limit the maximum accuracy achievable at the local scale.

Figure $2 \mathrm{a}-\mathrm{d}$ shows the average annual GPP fluxes observed and simulated for all four study sites. As expected, the linear corrections applied to the E-OBS temperatures produce marginal effects, i.e. differences in mean annual GPP lower than $3 \%$; consequently, the results of the simulations with corrected temperatures are not shown. Slightly higher differences are obtained from the rainfall correction, whose results are reported in the same figures.

Figure 2a shows mean GPP fluxes for Soroe, which is situated close to sea level (Table 1). The mean observed growing season lasts from about day 90 to day 290 and is correctly reproduced by the model. BIOME-BGC instead fails to reproduce the clear GPP peak that is observed in late spring; the reference GPP maximum reaches $16 \mathrm{~g} \mathrm{C} \mathrm{m}^{-2} \mathrm{day}^{-1}$, whereas the model, in both the original and corrected configuration, yields peak estimates around $12 \mathrm{~g} \mathrm{C} \mathrm{m}^{-2} \mathrm{day}^{-1}$. The E-OBS rainfall values are underestimated, but the correction applied only gives a minor improvement in the determination coefficients, since water availability is usually guaranteed by the deep soil.

Figure $2 \mathrm{~b}$ shows the observed and estimated mean GPP fluxes for Hainich, which is situated at $430 \mathrm{~m}$ a.s.l. The growing season lasts about 6 months long, from mid-spring to midautumn, and the full canopy development simulated by the model is faster than that observed at this site. The observed maximum GPP peak is about $12 \mathrm{~g} \mathrm{C} \mathrm{m}^{-2}$ day $^{-1}$, while the simulated is lower (around $11 \mathrm{~g} \mathrm{C} \mathrm{m}^{-2}$ day $^{-1}$ ). The two simulated annual fluxes are almost identical due to the accuracy of the 1-km E-OBS rainfall dataset (measured annual average of 806 versus $757 \mathrm{~mm}$ ). The global agreement is good $\left(r^{2}>0.825\right)$, but the model overestimates and underestimates GPP in spring and summer, respectively.

GPP evolution for Hesse is shown in Fig. 2c. The growing season is slightly longer than in the previous sites, and the annual peak is similar to that observed for Hainich. The start of the growing season simulated by BIOME-BGC is earlier than that of the tower observations, while the maximum peak is well reproduced. Also in this case, the slight rainfall underestimation of the E-OBS dataset causes only marginal changes in simulated GPP due to the deep soil.

Figure $2 \mathrm{~d}$ refers to Collelongo, which is the most southern and elevated site (Table 1). The growing season in this forest is relatively brief (from late-spring till mid-autumn) and is not reproduced well by the model, which slightly anticipates the start and delays the end of the season. The total annual GPP observed by the tower is about $1400 \mathrm{~g} \mathrm{C} \mathrm{m}^{-2}$ year $^{-1}$ (Fig. 3), while the GPP simulated by both approaches is lower, mainly due to an underestimation during the driest summer months. The corrected rainfall is around $30 \%$ higher than the original and increases the simulated summer GPP, which, however, remains lower than that observed by the tower (MBE from -0.63 to $-0.30 \mathrm{~g} \mathrm{C} \mathrm{m}^{-2}$ day $^{-1}$ ).

The same accuracy statistics computed on a daily basis are shown in Table 4 for the entire data series. As expected, the global agreements are always lower than those obtained using the annual averages. The model shows a variable tendency to underestimation with the exception of Hesse. The accuracies achieved using the corrected dataset are still only slightly better than those obtained using the original $1-\mathrm{km}$ dataset.

This last finding is fundamentally confirmed when analyzing the spatial variability of the annual GPP averages. Figure 3 shows these annual averages observed and simulated using the two rainfall datasets; the marginal underestimation obtained with the original dataset is again slightly 


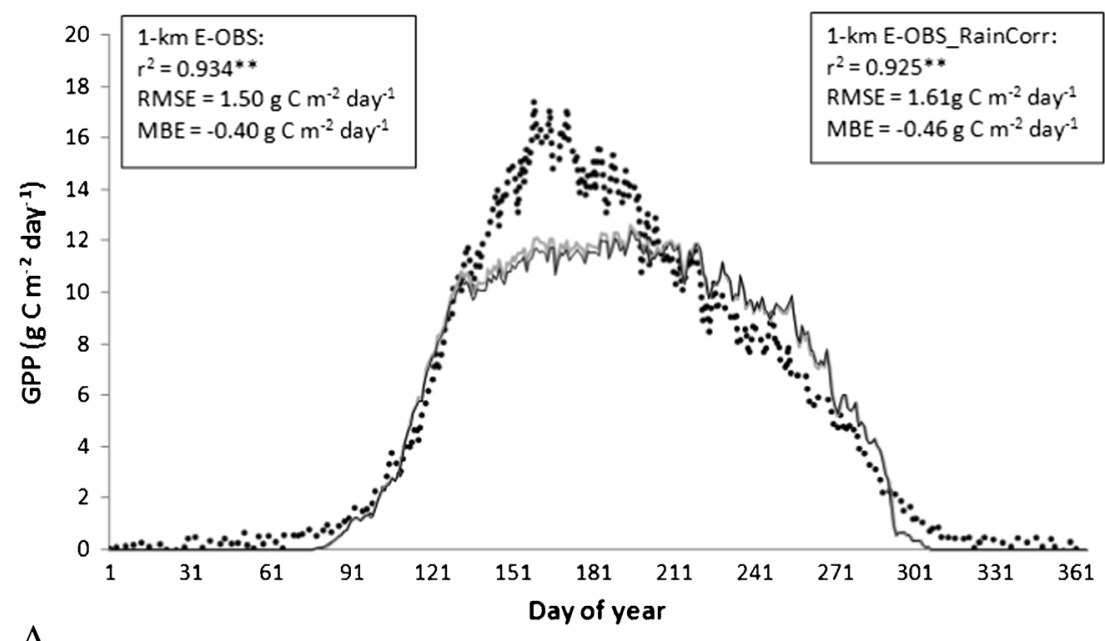

A

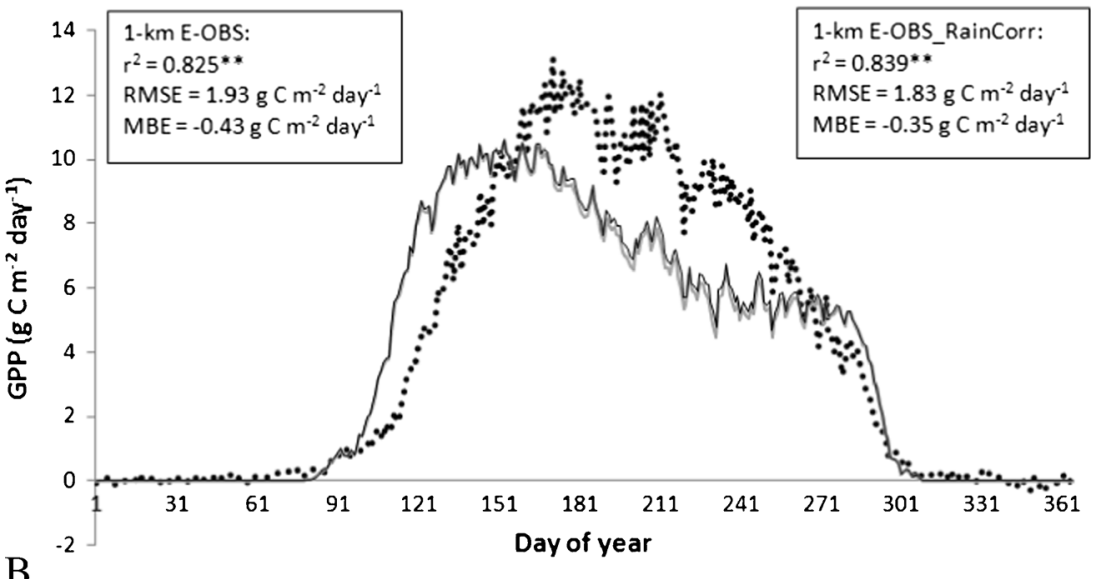

Fig. 2 Mean GPP evolution obtained from the tower observations (dotted black line) and applying BIOME-BGC fed with the original (grey line) and rainfall-corrected (black line) E-OBS datasets. The four graphs refer to Soroe (a), Hainich (b), Hesse (c) and Collelongo (d) (all correlation coefficients are highly significant, $P<0.01$ ) reduced by the rainfall correction (MBE from -70.5 to $-50.8 \mathrm{~g} \mathrm{C} \mathrm{m}^{-2}$ year $^{-1}$ ).

In summary, these results indicate that the use of the 1-km E-OBS dataset yields reasonable accuracies which are only marginally improved by the rainfall correction. On this basis, all following BIOME-BGC simulations were performed using the original dataset, which is obviously the only available at Pan-European level.

\subsection{Effect of spring temperature and spring-summer dryness}

The SDS dates that were found to divide the growing season into temperature and water-limited periods were all around the beginning of July, ranging from 24 June for Collelongo to 9 July for Hainich. The regression analyses between Tcor and Cws and observed GPP before and after these dates were not feasible in the case of Collelongo, for which the number of years with nearly complete daily GPP measurements (i.e. with less than 30 missing days per year) was insufficient for a regression. The analyses were instead possible for the other three sites, which had at least eight nearly complete years of measurements. The results of the regression analyses between spring Tcor and GPP of the first part of the growing season are shown in Fig. 4a. All correlations are high and significant $(P<0.05)$ for Hainich and highly significant $(P<0.01)$ for Hesse and Soroe. The regression slopes range from about $1000 \mathrm{~g} \mathrm{C} \mathrm{m}^{-2}$ day $^{-1}$ Tcor $^{-1}$ for Hainich and Soroe to $2200 \mathrm{~g}$ $\mathrm{C} \mathrm{m}^{-2}$ day $^{-1}$ Tcor $^{-1}$ for Hesse. Most differences among these slopes are due to the respective range of inter-annual GPP variation, which is narrowest for Hainich and widest for Hesse.

Figure $4 \mathrm{~b}$ shows the same results concerning the regressions between spring-summer Cws and GPP in the second part of the growing season. All correlations are positive but lower than those found for Tcor, in particular for Soroe and Hesse; the correlation is significant only for Hainich. The three regression slopes are quite similar and low, ranging from 

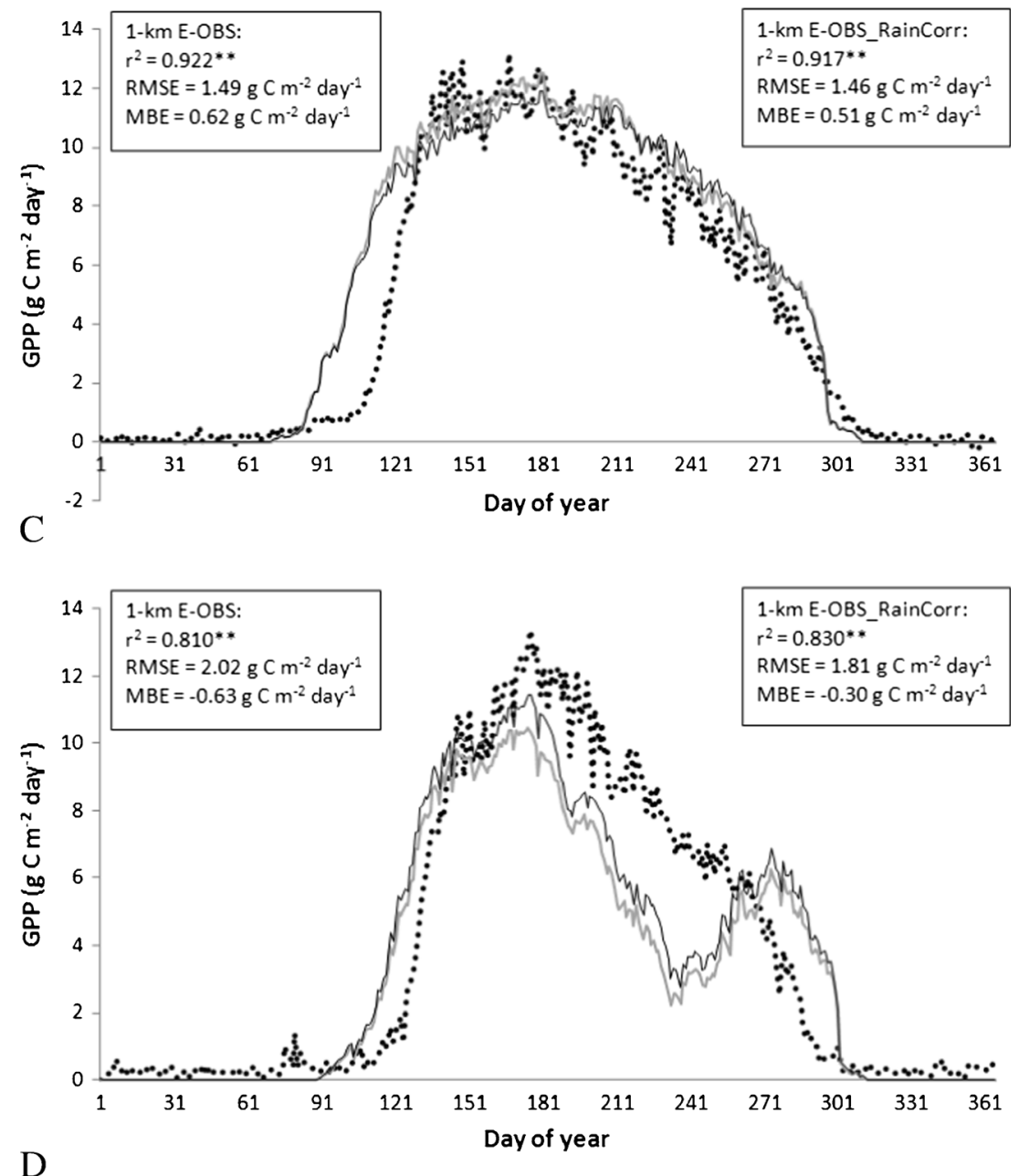

Fig. 2 continued.

about $750 \mathrm{~g} \mathrm{C} \mathrm{m}^{-2} \mathrm{day}^{-1} \mathrm{Cws}^{-1}$ for Soroe to $1160 \mathrm{~g}$ $\mathrm{C} \mathrm{m}^{-2}$ day $^{-1} \mathrm{Cws}^{-1}$ for Hesse.

The regressions performed between the same factors and the simulated GPP of the first and second parts of the season yielded the results summarized in Table 5. In the first case (Tcor on $\mathrm{GPP}_{1}$ ), the correlation coefficients are still all positive but lower than those in Fig. 4a; the correlation is significant for Collelongo and highly significant for Soroe. The regression slopes follow a
Fig. 3 Annual reference (dark grey) GPP averages of the four study sites compared to those obtained by BIOME-BGC fed with the original (medium grey) and rainfall-corrected (bright grey) datasets (the bars indicate the standard errors)

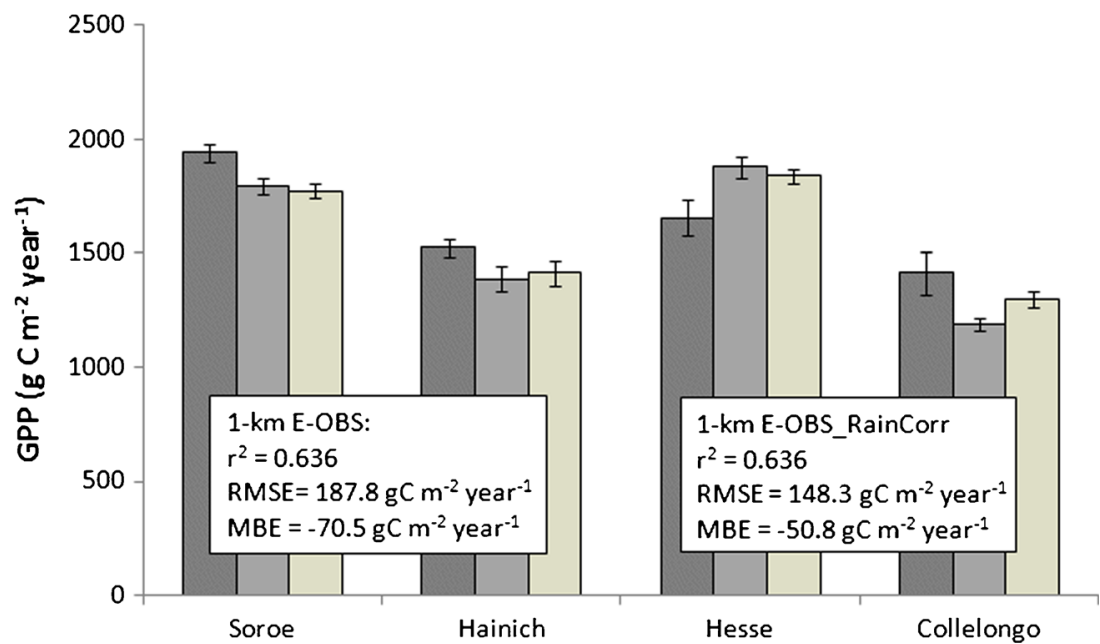


Table 4 Accuracy statistics obtained comparing the daily tower GPP observations to the BIOME-BGC estimates driven by the original and the corrected rainfall datasets (all correlations are highly significant, $P<0.01$ )

\begin{tabular}{|c|c|c|c|c|c|c|}
\hline \multirow[b]{2}{*}{ Site } & \multicolumn{3}{|c|}{ 1-km E-OBS dataset } & \multicolumn{3}{|c|}{ 1-km E-OBS with corrected rainfall } \\
\hline & $r^{2}$ & $\begin{array}{l}\text { RMSE (g } \\
\left.\mathrm{C} \mathrm{m}^{-2} \text { day }^{-1}\right)\end{array}$ & $\begin{array}{l}\operatorname{MBE}(\mathrm{g} \\
\left.\mathrm{C} \mathrm{m}^{-2} \mathrm{day}^{-1}\right)\end{array}$ & $r^{2}$ & $\begin{array}{l}\text { RMSE (g } \\
\left.\mathrm{C} \mathrm{m}^{-2} \text { day }^{-1}\right)\end{array}$ & $\begin{array}{l}\operatorname{MBE}(\mathrm{g} \\
\left.\mathrm{C} \mathrm{m}^{-2} \mathrm{day}^{-1}\right)\end{array}$ \\
\hline Soroe & 0.845 & 2.30 & -0.40 & 0.857 & 2.37 & -0.46 \\
\hline Hainich & 0.679 & 2.69 & -0.43 & 0.638 & 2.61 & -0.35 \\
\hline Hesse & 0.769 & 2.57 & 0.62 & 0.843 & 2.48 & 0.51 \\
\hline Collelongo & 0.540 & 3.20 & -0.64 & 0.712 & 3.14 & -0.30 \\
\hline
\end{tabular}

similar pattern, ranging from about $450 \mathrm{~g} \mathrm{C} \mathrm{m}^{-2}$ day $^{-1} \mathrm{Tcor}^{-1}$ for Hainich to $2000 \mathrm{~g} \mathrm{C} \mathrm{m}^{-2}$ day $^{-1}$ Tcor $^{-1}$ for Soroe. The effect of the water factor on the simulated GPP in the second part of the season is instead mostly overestimated. This is particularly evident for Hainich, where both correlation and slope are notably higher than those in Fig. 4 b.

\subsection{Impact of expected climate changes}

The results of the statistical analyses and simulation exercises concerning the impact of expected climate changes are compared in Fig. 5. The statistical analyses yield total GPP that always increases in the two scenarios, and particularly for A1B, mostly due to the positive effect of Tcor on GPP 1 . Cws instead exerts a lower depressive effect on $\mathrm{GPP}_{2}$, due to the increased evaporative demand caused by the two scenarios that is only partly counteracted by the increased rainfall. More particularly, the $\mathrm{GPP}_{2}$ decrements due to Cws decreases are around $23 \%$ of corresponding $\mathrm{GPP}_{1}$ increments due to Tcor increases. The total GPP increments from the statistical analyses are around 50-90 and 110-180 $\mathrm{g} \mathrm{C} \mathrm{m}^{-2}$ year $^{-1}$ for the E1 and A1B scenarios, respectively. BIOME-BGC simulates similar increments for Soroe and Hesse, while lower increments are obtained for Hainich. The projection uncertainties obtained from the statistical analyses are higher than those from BIOME-BGC simulations mainly due to the low correlations in Fig. 4b, but the differences between the two prediction methods are generally not significant.

\section{Discussion}

This paper investigates the possibility of simulating a major ecosystem process (GPP) for one of the most widespread European tree species, beech, using a recently produced continental daily weather dataset. This simulation, which is also a fundamental step forward towards the analysis of beech response to possible environmental changes, involves several critical aspects mostly related to the input data used and the model logic and parameter settings. These topics will be treated separately in the next two subsections, followed by a discussion on the impact of major climatic factors (i.e. rainfall and temperature) and the effect of expected climate changes.

\subsection{Input data used}

The assessment of model performances strictly depends on the adopted model inputs, whose accuracy will be briefly discussed here.

The 1-km weather dataset currently used to drive BIOMEBGC has been produced by Moreno and Hasenauer (2015) as a downscaled version of the original $0.25^{\circ}$ E-OBS dataset. Due to the well-known difficulty in extending ground point measurements over large areas (Hofstra et al. 2009), these meteorological data are associated with different levels of accuracy depending on the considered variable. In general, rainfall is more difficult to interpolate/extrapolate than temperature, due to its greater spatial variability and to its more irregular dependence on the main orographic and geographic factors (elevation, latitude, continentality, etc.) (Thornton et al. 1997). This trend was confirmed for the E-OBS dataset by research conducted in Italy by Maselli et al. (2012), which indicated that daily temperatures are estimated quite accurately while rainfall is variably underestimated. Similar results are found in the current investigation, according to which the 1$\mathrm{km}$ E-OBS mean temperature errors are small for all sites while this is not the case for rainfall, which is variably underestimated (Table 2); the possible impact of this rainfall underestimation is discussed in the next section. Among the other meteorological drivers, radiation exerts a major effect on the simulation of GPP (Waring and Running 2010). The accuracy of the radiation estimates obtained by MT-CLIM in Central Europe was assessed by Thornton et al. (2000), who found reasonable precision and accuracy also in rugged terrain conditions. Those findings are confirmed by the current analyses versus tower measurements (data not shown), which indicate that mean radiation errors are relatively small (up to $10 \%$ ) and temporally variable. In particular, periods of underestimation and overestimation are found at each site that could be partly due to the problematic functioning and/or tuning of the sensors utilized for the ground measurements. 


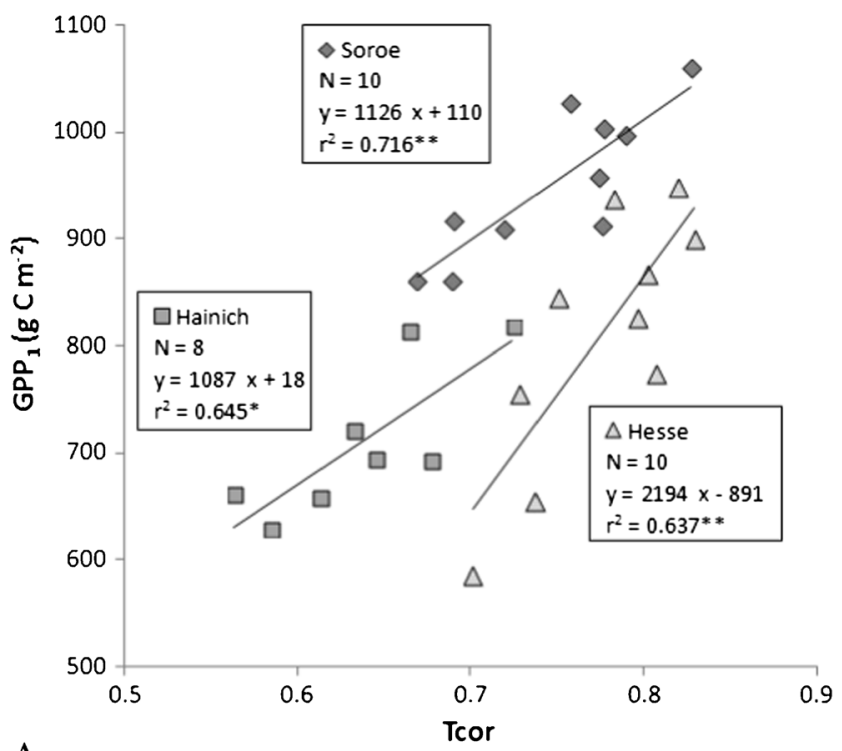

A

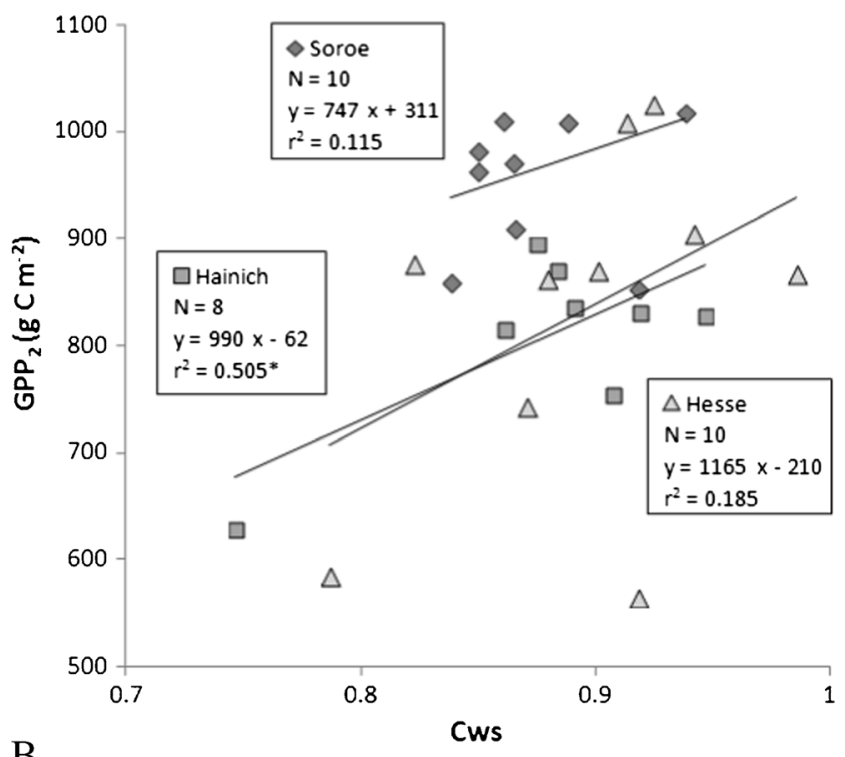

B

Fig. 4 a Linear regressions between mean spring temperature correction factor (Tcor; adimensional) and reference GPP of the first part of the growing season $\left(\mathrm{GPP}_{1}\right)$ for Soroe, Hainich and Hesse. b Linear regressions between mean spring-summer water stress factor (Cws; adimensional) and reference GPP of the second part of the growing season $\left(\mathrm{GPP}_{2}\right)$ for the same three sites (in both cases, Collelongo was excluded due to the lack of complete annual GPP data, see text for details) $\left({ }^{*} P<0.05\right.$, significant correlation; ${ }^{*} P<0.01$, highly significant correlation)

As regards the other model inputs, BIOME-BGC is particularly sensitive to soil features and particularly to depth (Chiesi et al. 2011). This can be explained by the simplified model treatment of the site water budget, which considers a unique soil layer without horizontal water displacements (Running and Hunt 1993). At regional scale, soil information can be derived from currently available Pan-European maps, which, however, are affected by high uncertainty due to the notable spatial heterogeneity of soil features (see http:// eusoils.jrc.ec.europa.eu/). A possible alternative is the use of a standard soil depth of $1 \mathrm{~m}$ to drive the model, which could be preferable when the available soil information is suspected to be inaccurate. In this regard, it should be noted that the soil rooting depth that guides BIOME-BGC simulations may not correspond to the soil depth measured "in situ", particularly in rugged, heterogeneous terrains. In these cases, in fact, the actual soil depth is spatially variable, which can locally increase the soil layer explored by tree roots. Some experimental trials confirm that the use of a standard soil depth reduces the excessive model sensitivity to the water factor at Hainich and Collelongo (results not shown). Soil texture is instead less influential, leading to only minor changes of predicted GPP. These results highlight the importance of using correct soil depth information to drive BIOME-BGC, which would be even more necessary for future climate simulations.

\subsection{Model logic and parameter setting}

A full discussion about the potential of BIOME-BGC logic to simulate the main processes of temperate-humid forest ecosystems can be found in Pietsch and Hasenauer (2002), Churkina et al. (2003) and Jochheim et al. (2009). These investigations showed that the model is generally capable of reproducing the seasonal growth of these ecosystems, with particular reference to the continent of Europe. These authors also recognized the importance of a proper model parameter setting and of using good quality input data for correctly estimating the carbon budget of forest ecosystems.

The beech parameter setting adopted here was identified during a calibration exercise performed in Italy by Chiesi et al. (2007). As previously noted, however, the maximum photosynthetic efficiency and stomata conductance were modified following Pietsch et al. (2005) and Chirici et al. (2016) in order to cope with more diversified environmental conditions and consequent stronger limitations that characterize the current model applications. The correctness of this choice was confirmed by the good accuracy obtained in the simulation of GPP for all four study sites. A residual tendency to underestimating GPP remains in the most northern site, Soroe, mainly due to the incorrect reproduction of the high late spring GPP peak. In general, these results support the use of high maximum photosynthetic efficiency and low stomata conductance for simulating forest carbon fluxes at the continental level, where a variety of environmental conditions can limit the growth of tree species. On the other hand, the use of the complete parameter settings of Pietsch et al. (2005) led to slightly decrease the simulation accuracy due to the prediction of lower GPP values during summer water stress periods (results not shown).

The effect of water stress on GPP remains, however, a critical point for the current simulations. The adopted version of 
Table 5 Determination coefficients and slopes found from the regression analyses between mean spring Tcor and spring/summer Cws (independent variables) and annual GPP simulated by BIOME-BGC in the first and second part of the growing season, respectively (dependent variables)

\begin{tabular}{|c|c|c|c|c|}
\hline Site & $r^{2}$ Tcor/GPP 1 & $\begin{array}{l}\text { Slope Tcor/GPP } \\
\left(\mathrm{g} \mathrm{C} \mathrm{m}^{-2} \text { day }^{-1} \text { Tcor }^{-1}\right)\end{array}$ & $r^{2} \mathrm{Cws} / \mathrm{GPP}_{2}$ & $\begin{array}{l}\text { Slope Cws/GPP } \\
\left(\mathrm{g} \mathrm{C} \mathrm{m}^{-2} \text { day }^{-1} \mathrm{Cws}^{-1}\right)\end{array}$ \\
\hline Soroe & $0.662 * *$ & 1996 & 0.185 & 537 \\
\hline Hainich & 0.069 & 453 & $0.812^{* *}$ & 1543 \\
\hline Hesse & 0.306 & 1228 & $0.611^{* *}$ & 1193 \\
\hline Collelongo & $0.506^{*}$ & 1608 & $0.525^{*}$ & 1850 \\
\hline
\end{tabular}

$N=10$

${ }^{*} P<0.05$, significant correlation; $* * P<0.01$, highly significant correlation

BIOME-BGC is, in fact, likely still too sensitive to summer water shortage, as shown by the results for Hainich and, above all, Collelongo. In this last case, summer dryness is particularly evident and determines a clear drop in simulated GPP which is not observed for the tower data. This problem adds to that coming from the variable underestimation of total rainfall, which can increase the model oversensitivity to water stress. The effects of this underestimation, however, are generally attenuated by the relative rarity of strong water limitation events for beech, which generally grows in temperate-humid areas. This is confirmed by the current findings, which indicate that the use of the uncorrected 1-km E-OBS rainfall estimates implies only a marginal worsening of BIOME-BGC performances. A similar reasoning applies to the possible inaccuracy in the reproduction of actual rainfall patterns by the downscaled E-OBS dataset, whose effects could not be assessed. Water availability, however, can become an important controlling factor during extremely dry summer seasons, such as that of 2003, when beech production in Europe was strongly limited by the well-known heat and drought wave (Ciais et al. 2005; Granier et al. 2007). This is also supported by both the current observations and model simulations for all sites except Soroe, where the heat wave was less effective; in all other cases, the 2003 summer GPP was markedly lower than the multi-year average (data not shown).

The model configuration applied identifies the start and end of the growing season by the model phenology subroutine (White et al. 1997). This subroutine is known to suffer from a critical functioning in areas that differ from those temperatecold for which it was originally tuned (Trusilova et al. 2009). In particular, these authors found that the subroutine can predict the end better than the start of the season. Such findings agree with those from the current experiments, which indicate that the end of the growing season is predicted well for three sites (Soroe, Hainich and Hesse), while the start of the season is predicted well only for Soroe. The simulated start of the growing season is instead variably anticipated for Hainich, Hesse and Collelongo; in the last case, the end of the season is also delayed. The model difficulty in capturing the start of the growing season is likely due to the higher dependence of beech bud break on day length than on temperature (Falusi and Calamassi 1997). This would suggest a need to improve the model subroutine concerning the synchronized accounting for the effects of temperature, radiation and day length (see also the following subsection).
Fig. 5 Effects of the two climate scenarios on annual beech GPP predicted by the linear regressions of Fig. 4 (dark grey) and simulated by BIOME-BGC (bright grey) (the bars indicate the standard errors; $* P<0.05$, significant correlation)

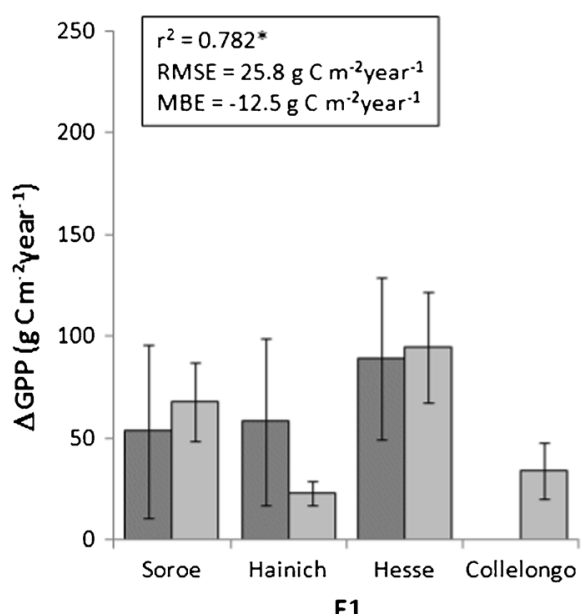

E1

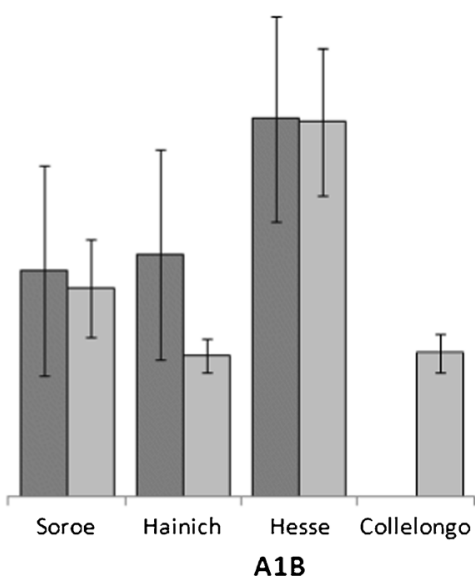

INA פ פsrieger 


\subsection{Impact of climatic factors}

The previous considerations highlight the importance of air temperature as the environmental variable that usually most affects beech growth, particularly during spring. Spring temperature, in fact, directly influences the start of the growing period and consequently its total length and intensity (Myneni et al. 1997; Jolly and Running 2004; Delpierre et al. 2009). The relevance of this factor has been assessed through statistical analyses of tower GPP observations. The results obtained support the relevance of spring temperature in determining beech production in all examined sites. In particular, this factor explains most of the inter-annual GPP variability in the first part of the season $\left(r^{2}>0.64\right.$ for the three sites). This is in accordance with Lebourgeois et al. (2012), who found a positive effect of April temperature on the growth of Pinus nigra that increased moving towards higher altitudes. As spring temperatures determine leaf unfolding and cambial reactivation, warmer springs can modify the timing of leaf development, wood formation and photosynthetic activity enhancing growth and carbon uptake (Lebourgeois et al. 2010; Delpierre et al. 2009).

The statistical analyses of the tower GPP observations also indicate the secondary importance of the water factor in driving inter-annual beech GPP variations. In general, water limitation is restricted to the summer and is variably effective, depending on both climatic and edaphic conditions. More specifically, spring-summer dryness affects the GPP in the second part of the season to a degree which is lower and more irregular than that of the thermal factor.

The regression analyses performed on the model simulations confirm that the version of BIOME-BGC used is still too sensitive to the water factor, particularly in the area with the shallowest soil depth (Hainich). This behaviour can again be explained by the previous considerations on the model inputs and functioning.

\subsection{Effects of expected climate changes}

A final experiment analysed the effects of expected climate changes on beech production. While a complete simulation of future climate scenarios would have required the consideration of multiple concurring factors (IPPC 2014), the current simplified approach focused on assessing the impact of expected temperature and rainfall increases on beech GPP. More specifically, two basic temperature and rainfall scenarios were used corresponding to different mitigation conditions, E1 and A1B. The effects of these scenarios were evaluated using two independent methods, i.e. projecting the linear equations previously defined based on GPP observations and applying new
BIOME-BGC simulations. The results of the two methods are generally concordant, indicating that GPP levels progressively rise with increasing temperatures and rainfall. A major discrepancy is found only for the most continental site, Hainich, where the GPP increments from the statistical analysis are notably higher than those from BIOME-BGC simulations. This pattern can be attributed to the previously noted excessive sensitivity of BIOMEBGC to water limitation, which is exacerbated by the shallow soil in this site.

\section{Conclusions}

The research concerned the analysis of GPP patterns in four European beech sites representative of various environmental conditions. The following main conclusions can be drawn from the experiment:

1. The considered Pan-European 1-km daily weather dataset can drive BIOME-BGC for reproducing the tower GPP observations of the examined ecosystems with reasonable levels of accuracy.

2. The observed annual GPP of these ecosystems is primarily sensitive to air temperature around the beginning of the growing season. A secondary effect is exerted by springsummer dryness.

3. The GPPs simulated by BIOME-BGC follow a similar pattern but with a higher sensitivity to water limitation that depends mainly on soil characteristics.

4. The proposed modelling approach can approximately simulate the effects of expected temperature and rainfall increases in all examined sites, with some limits related to the critical accounting for the water factor.

It can consequently be concluded that, in spite of some limitations of both the input data and model used, BIOME-BGC fed with the 1-km E-OBS dataset can be a prognostic tool for simulating beech GPP variations consequent to expected climate changes over the continent of Europe.

Acknowledgments The authors acknowledge the E-OBS dataset from the EU-FP6 ENSEMBLES Project (http://ensembles-eu.metoffice.com) and the data providers in the ECA\&D Project (http://eca.knmi.nl). Thanks are also due to the AFS Editors and anonymous reviewers for their precious comments on the original manuscript.

The current research was partially funded by the EU-FP7 FORMIT Project, "FORest management strategies to enhance the MITigation potential of European forests" (grant agreement no. 311970). 


\section{Appendix}

Table 6 Parameter settings of BIOME-BGC utilised for beech (see text for details)
Keyword

Fagus sylvatica (DBF)

Transfer growth period as fraction of growing season (prop.)

Litterfall as fraction of growing season (prop.)

Annual leaf and fine root turnover fraction (1/year)

1

Annual live wood turnover fraction (1/year)

Annual whole plant mortality fraction (1/year)

0.007143

Annual fire mortality fraction (1/year)

0

Allocation new fine root $\mathrm{C} /$ new leaf $\mathrm{C}$ (ratio)

Allocation new stem $\mathrm{C} /$ new leaf $\mathrm{C}$ (ratio)

Allocation new live wood $\mathrm{C} /$ new total wood $\mathrm{C}$ (ratio)

Allocation new coarse root $\mathrm{C} /$ new stem $\mathrm{C}$ (ratio)

Allocation current growth proportion (prop.)

$\mathrm{C} / \mathrm{N}$ of leaves $(\mathrm{kg} \mathrm{C} / \mathrm{kg} \mathrm{N})$

$\mathrm{C} / \mathrm{N}$ of leaf litter $(\mathrm{kg} \mathrm{C} / \mathrm{kg} \mathrm{N})$

$\mathrm{C} / \mathrm{N}$ of fine roots $(\mathrm{kg} \mathrm{C} / \mathrm{kg} \mathrm{N})$

$\mathrm{C} / \mathrm{N}$ of live wood $(\mathrm{kg} \mathrm{C} / \mathrm{kg} \mathrm{N})$

$\mathrm{C} / \mathrm{N}$ of dead wood $(\mathrm{kg} \mathrm{C} / \mathrm{kg} \mathrm{N})$

Leaf litter labile proportion (dim)

Leaf litter cellulose proportion (dim)

Leaf litter lignin proportion (dim)

Fine root labile proportion (dim)

Fine root cellulose proportion (dim)

Fine root lignin proportion (dim)

Dead wood cellulose proportion (dim)

Dead wood lignin proportion (dim)

0.23

Canopy water interception coefficient (1/LAI/day)

0.045

Canopy light extinction coefficient (dim)

All sided to projected leaf area ratio (dim)

2

Canopy average specific leaf area $\left(\mathrm{m}^{2} / \mathrm{kg} \mathrm{C}\right)$

Ratio of shaded SLA/sunlit SLA (dim)

2

Fraction of leaf $\mathrm{N}$ in Rubisco (dim)

Maximum stomatal conductance $(\mathrm{m} / \mathrm{s})$

Cuticular conductance $(\mathrm{m} / \mathrm{s})$

Boundary layer conductance $(\mathrm{m} / \mathrm{s})$

0.01

$-0.34$

$-2.2$

1100

Vapour pressure deficit: start of conductance reduction $(\mathrm{Pa})$

3600 


\section{References}

Aranda I, Gil L, Pardos JA (2000) Water relations and gas exchange in Fagus sylvatica L. and Quercus petraea (Mattuschka) Liebl. in a mixed stand at their southern limit of distribution in Europe. Trees 14:344-352

Aubinet M, Grelle A, Ibrom A, Rannik U, Moncrieff J, Foken T, Kowalski AS, Martin PH, Berbigier P, Bernhofer C, Clement R, Elbers J, Granier A, Grunwald T, Morgenstern K, Pilegaard K, Rebmann C, Snijders W, Valentini R, Vesala T (2000) Estimates of the annual net carbon and water exchange of forests: the EUROFLUX methodology. Adv Ecol Res 30:113-175

Baldocchi DD (2003) Assessing ecosystem carbon balance: problems and prospects of the eddy covariance technique. Global Change Biol 9:479-492

Bohn U, Gollub G, Hettwer C, Weber H, Neuhäuslová Z, Raus T, Schlüter H (2004) Interactive CD-Rom map of the natural vegetation of Europe. Version 2.0. In: Federal Agency for Nature Conservation. Available on-line at: http://www.floraweb.de/ vegetation/dnldeurovegmap.html

Bolte A, Czajkowski T, Kompa T (2007) The north-eastern distribution range of European beech-a review. Forestry 80(4). doi:10.1093/ forestry/cpm028

Bréda N, Huc R, Granier A, Dreyer E (2006) Temperate forest trees and stands under severe drought: a review of ecophysiological responses, adaptation processes and long-term consequences. Ann For Sci 63:625-644

Chiesi M, Maselli F, Bindi M, Fibbi L, Cherubini P, Arlotta E, Tirone G, Matteucci G, Seufert G (2005) Modelling carbon budget of Mediterranean forests using ground and remote sensing measurements. Agric For Meteor 135:22-34

Chiesi M, Maselli F, Moriondo M, Fibbi L, Bindi M, Running SW (2007) Application of BIOME-BGC to simulate Mediterranean forest processes. Ecol Model 206:179-190

Chiesi M, Fibbi L, Genesio L, Gioli B, Magno R, Maselli F, Moriondo M, Vaccari F (2011) Integration of ground and satellite data to model Mediterranean forest processes. Int J Appl Earth Obs Geoinf 13: 504-515

Chirici G, Chiesi M, Corona P, Salvati R, Papale D, Fibbi L, Sirca C, Spano D, Duce P, Marras S, Matteucci G, Cescatti A, Maselli F (2016) Estimating daily forest carbon fluxes using the combination of ground and remotely sensed data. J Geophys Res Biogeosci, 121, doi: 10.1002/2015JG003019.

Chiti T, Papale D, Smith P, Dalmonech D, Matteucci G, Yeluripati J, Rodeghiero M, Valentini R (2010) Predicting changes in soil organic carbon in Mediterranean and alpine forests during the Kyoto Protocol commitment periods using the CENTURY model. Soil Use Manag 26:475-484

Churkina G, Tenhunen J, Thornton P, Falge EM, Elbers JA, Erhard M, Grünwald T, Kowalski AS, Rannik U, Sprinz D (2003) Analyzing the ecosystem carbon dynamics of four European coniferous forests using a biogeochemistry model. Ecosystems 6:168-184

Christensen OB, Goodess CM, Harris I, Watkiss P (2011) European and global climate change projections: discussion of climate change model outputs, scenarios and uncertainty in the EC RTD ClimateCost project. In: Watkiss P (ed) The ClimateCost project. Final report. Volume 1: Europe. Stockholm Environment Institute, Sweden

Ciais P, Reichstein M, Viovy N, Granier A, Ogée J, Allard V, Aubinet M, Buchmann N, Chr B, Carrara A, Chevallier F, De Noblet N, Friend $\mathrm{AD}$, Friedlingstein $\mathrm{P}$, Grünwald T, Heinesch B, Keronen P, Knohl A, Krinner G, Loustau D, Manca G, Matteucci G, Miglietta F, Ourcival JM, Papale D, Pilegaard K, Rambal S, Seufert G, Soussana JF, Sanz MJ, Schulze ED, Vesala T, Valentini R (2005) Europe-wide reduction in primary productivity caused by the heat and drought in 2003. Nature 437:529-533

Delpierre N, Soudani K, Francois C, Kostner B, Pontailler JY, Nikinmaa E, Misson L, Aubinet M, Bernhofer C, Granier A, Grunwald T, Heinesch B, Longdoz B, Ourcival JM, Rambal S, Vesala T, Dufrene E (2009) Exceptional carbon uptake in European forests during the warm spring of 2007: a data-model analysis. Glob Change Biol 15:1455-1474

Ellenberg H (1988) Vegetation ecology of central Europe, 4th edn. Cambridge University Press, Cambridge

Falusi M, Calamassi R (1997) Bud dormancy in Fagus sylvatica L. I. Chilling and photoperiod as factors determining budbreak. Plant Biosyst 131:67-72

Granier A, Reichstein M, Bréda N, Janssens IA, Falge E, Ciais P, Grünwald T, Aubinet M, Berbigier P, Bernhofer C, Buchmann N, Facini O, Grassi G, Heinesch B, Ilvesniemi H, Keronen P, Knohl A, Köstner B, Lagergren F, Lindroth A, Longdoz B, Loustau D, Mateus J, Montagnani L, Nys C, Moors E, Papale D, Peiffer M, Pilegaard K, Pita G, Pumpanen J, Rambal S, Rebmann C, Rodrigues A, Seufert G, Tenhunen J, Vesala T, Wang Q (2007) Evidence for soil water control on carbon and water dynamics in European forests during the extremely dry year: 2003. Agric For Met 143:123-145

Granier A, Bréda N, Longdoz B, Gross P, Ngao J (2008) Ten years of fluxes and stand growth in a young beech forest at Hesse, Northeastern France. Ann For Sci 65:704. doi:10.1051/forest:2008052

Guidolotti G, Rey A, D’Andrea E, Matteucci G, De Angelis P (2013) Effect of environmental variables and stand structure on ecosystem respiration components in a Mediterranean beech forest. Tree Physiol 33:960-972

Haylock MR, Hofstra N, Klein Tank AMG, Klok EJ, Jones PD, New M (2008) A European daily high-resolution gridded dataset of surface temperature and precipitation. J Geoph Res (Atmospheres) 113, D20119. doi:10.1029/2008JD10201

Heinsch FA, Reeves M, Votava P, Kang S, Milesi C, Zhao M, Glassy J, Jolly WM, Loehman R, Bowker CF, Kimball JS, Nemani RR, Running SW (2003) User's guide: GPP and NPP (MOD17A2/A3) products, NASA MODIS Land algorithm, Version 2.0. Missoula, University of Montana. www.ntsg.umt.edu/modis/

Hofstra N, Haylock M, New M, Jones PD (2009) Testing E-OBS European high-resolution gridded data set of daily precipitation and surface temperature. J Geophys Res 114, D21101. doi:10. 1029/2009JD011799

Huber MO, Eastaugh CS, Gschwantner T, Hasenauer H, Kindermann G, Ledermann T, Lexer MJ, Rammer W, Schörghuber S, Sterba H (2013) Comparing simulations of three conceptually different forest models with national forest inventory data. Environ Model Softw 40:88-97

Ichii K, Hashimoto H, Nemani R, White M (2005) Modeling the interannual variability and trends in gross and net primary productivity of tropical forests from 1982 to 1999. Global Planet Change 48:274286

IPPC (2014) Climate change 2014. IPPC Fifth assessment report. Available from: http://www.ipcc.ch/

Iqbal M (1983) An introduction to solar radiation. Academic, New York Jensen ME, Heise HR (1963) Estimating evapotranspiration from solar radiation. J Irrig Drain Div ASCE 89:15-41

Jochheim H, Puhlmann M, Beese F, Berthold D, Einert P, Kallweit R, Konopatzky A, Meesenburg H, Meiwes K-J, Raspe S, SchulteBisping H, Schulz C (2009) Modelling the carbon budget of intensive forest monitoring sites in Germany using the simulation model BIOME-BGC. IForest 2:7-10

Jolly WM, Running SW (2004) Effects of precipitation and soil water potential on drought deciduous phenology in the Kalahari. Global Change Biol 10:303-308 
Knohl A, Schulze E-D, Kolle O, Buchmann N (2003) Large carbon uptake by an unmanaged 250-year-old deciduous forest in Central Germany. Agric For Meteor 118:151-167

Law BE, Turner D, Campbell D, Sun OJ, Van Tuyl S, Ritts WD, Cohen WB (2004) Disturbance and climate effects on carbon stocks and fluxes across Western Oregon USA. Global Change Biol 10:14291444

Lebourgeois F, Pierrat JC, Perez V, Piedallu C, Cecchini S, Ulrich E (2010) Simulating phenological shifts in French temperate forests under two climatic change scenarios and four driving GCMs. Int J Biometeor 54:563-581

Lebourgeois F, Mérian P, Courdier F, Ladier J, Dreyfus P (2012) Instability of climate signal in tree-ring width in Mediterranean mountains: a multi-species analysis. Trees 26:715-729

Maselli F, Pasqui M, Chirici G, Chiesi M, Fibbi L, Salvati R, Corona P (2012) Modeling primary production using a $1 \mathrm{~km}$ daily meteorological data set. Clim Res 54:271-285

Maselli F, Cherubini P, Chiesi M, Gilabert MA, Lombardi F, Moreno A, Teobaldelli M, Tognetti R (2014) Start of the dry season as a main determinant of inter-annual Mediterranean forest production variations. Agric For Meteor 194:197-206

Moreno A, Hasenauer H (2015) Spatial downscaling of European climate data. Inter J Clim. doi:10.1002/joc.4436

Mund M (2004) Carbon pools of European beech forests (Fagus sylvatica) under different silvicultural management. Berichte des Forschungszentrums Waldökosysteme, Reihe A, Band 189, Forschungszentrum Waldökosysteme der Universität Göttingen, Göttingen

Mund M, Kutsch WL, Wirth C, Kahl T, Knohl A, Skomarkova MV, Schulze E-D (2010) The influence of climate and fructification on the inter-annual variability of stem growth and net primary productivity in an old growth, mixed beech forest. Tree Physiol 30:689704

Myneni RB, Keeling CD, Tucker CJ, Asrar G, Nemani RR (1997) Increased plant growth in the northern high latitudes from 1981 to 1991. Nature 386:698-702

Pietsch SA, Hasenauer H (2002) Using mechanistic modeling within forest ecosystem restoration. For Ecol Manag 159:111-131

Pietsch SA, Hasenauer H, Thornton PE (2005) BGC-model parameters for tree species growing in central European forests. For Ecol Manag 211:264-295

Pilegaard K, Ibrom A, Courtney MS, Hummelshøj P, Jensen NO (2011) Increasing net $\mathrm{CO}_{2}$ uptake by a Danish beech forest during the period from 1996 to 2009. Agric For Meteor 151:934-946

Piovesan G, Biondi F, Di Filippo A, Alessandrini A, Maugeri M (2008) Drought-driven growth reduction in old beech (Fagus sylvatica L.) forests of the central Apennines, Italy. Global Change Biol 14:12651281

Pötzelsberger E, Wolfslehner B, Hasenauer H (2015) Climate change impacts on key forest functions of the Vienna Woods. Europ J For Res. doi:10.1007/s10342-015-0866-2

Powell SL, Cohen WB, Healey SP, Kennedy RE, Moisen GG, Pierce KB, Ohmann JL (2010) Quantification of live aboveground forest biomass dynamics with Landsat time-series and field inventory data: a comparison of empirical modeling approaches. Remote Sens Envir 114:1053-1068

Reichstein M, Falge E, Baldocchi D, Papale D, Aubinet M, Berbigier P, Bernhofer C, Buchmann N, Gilmanov T, Granier A, Grunwald T, Havrankova K, Ilvesniemi H, Janous D, Knohl A, Laurila T, Lohila A, Loustau D, Matteucci G, Meyers T, Miglietta F, Ourcival JM, Pumpanen J, Rambal S, Rotenberg E, Sanz M, Tenhunen J, Seufert G, Vaccari F, Vesala T, Yakir D, Valentini R (2005) On the separation of net ecosystem exchange into assimilation and ecosystem respiration: review and improved algorithm. Global Change Biol 11:1424-1439

Running SW, Hunt ER (1993) Generalization of a forest ecosystem process model for other biomes, BIOME-BGC, and an application for global-scale models. In: Ehleringer JR, Field CB (eds) Scaling physiological processes: leaf to globe. Academic, San Diego, pp 141158

Scartazza A, Moscatello S, Matteucci G, Battistelli A, Brugnoli E (2013) Seasonal and inter-annual dynamics of growth, non-structural carbohydrates and $\mathrm{C}$ stable isotopes in a Mediterranean beech forest. Tree Physiol 33:730-742

Tatarinov FA, Cienciala E (2009) Long-term simulation of the effect of climate changes on the growth of main Central-European forest tree species. Ecol Mod 220:3081-3088

Thornton PE, Running SW, White MA (1997) Generating surfaces of daily meteorological variables over large regions of complex terrain. J Hydrol 190:214-251

Thornton PE, Hasenauer H, White MA (2000) Simultaneous estimation of daily solar radiation and humidity from observed temperature and precipitation: an application over complex terrain in Austria. Agric For Meteor 104:255-271

Trusilova K, Trembath J, Churkina G (2009) Parameter estimation and validation of the terrestrial ecosystem model BIOME-BGC using eddy-covariance flux measurements. Technical Reports - MaxPlanck-Institut für Biogeochemie 16:62

Turner DP, Ritts WD, Zhao M, Kurc SA, Dunn AL, Wofsy SC, Small EE, Running SW (2006) Assessing interannual variation in MODISbased estimates of gross primary production. IEEE Trans Geosc Remote Sens 44:1899-1909

Ueyama M, Harazono Y, Kim Y, Tanaka N (2009) Response of the carbon cycle in sub-arctic black spruce forests to climate change: reduction of a carbon sink related to the sensitivity of heterotrophic respiration. Agric For Meteor 149:582-602

Vitale M, Mancini M, Matteucci G, Francesconi F, Valenti R, Attorre F (2012) Model-based assessment of ecological adaptations of three forest tree species growing in Italy and impact on carbon and water balance at national scale under current and future climate scenarios. IForest 5:235-246

Waring RH, Running SW (2010) Forest ecosystems: analysis at multiple scales (Google eBook). Elsevier

White MA, Thornton PE, Running SW (1997) A continental phenology model for monitoring vegetation response to interannual climatic variability. Global Biogeoch Cycles 11:217-234

Zhu A-X (1997) A similarity model for representing soil spatial information. Geoderma 77:217-242 